\title{
TORWEGIAN FILM DAYS IN IAŞI. ALEXANDRU IOAN CUZA UNIVERSITY OF IAŞI, MAY 27-29, 2012. INTERVIEW WITH JAN ERIK HOLST
}

\section{Ioana Grecu and Crina Leon}

Alexandru Ioan Cuza University of Iaşi. E-mail: crina_laurentiu@yahoo.no

The Alexandru Ioan Cuza University of Iaşi in collaboration with the Norwegian Film Institute in Oslo and the Royal Norwegian Embassy in Bucharest organized the event entitled Norwegian Film Days in Iaşi, between May 27-29, 2012. This cultural event was coordinated by Dr. Crina Leon.

The guest speaker was Mr. Jan Erik

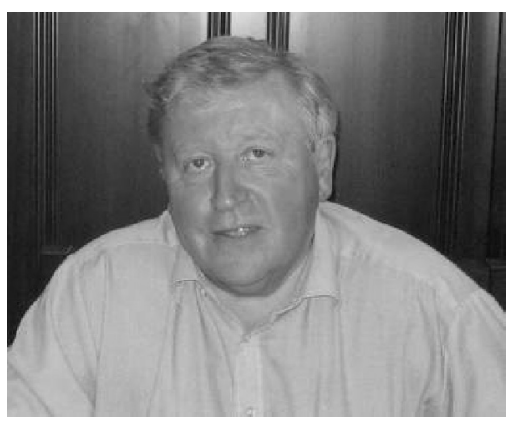
Holst, executive editor at the Norwegian Film Institute and responsible for major cultural projects abroad. He had previously been invited to Romania for similar projects in Cluj-Napoca and Bucharest.

The event was opened by a lecture given by Mr. Holst with a view to the new wave of Norwegian cinema (Norwave). In addition, he led discussions with the participants on each of the three days. The five feature films which were shown also belonged to the Norwave period, and offered a glimpse of Norwegian history, geography and literature. Yohan - The Child Wanderer (2010) was inspired by the labour migration of children between the counties of Vest-Agder and Aust-Agder more than 100 years ago, Max Manus (2008) was based on the German occupation of Norway during World War II, An Enemy of the People (2005) was a screen version of Henrik Ibsen's play with the same title, The Kautokeino Rebellion (2008) dealt with the conflicts of 1852 between the Norwegian authority and the Sami people in northern Norway, while The Greatest Thing (2001) was a screen version of Bjørnstjerne Bjørnson's novel The Fisherman's Daughter. 


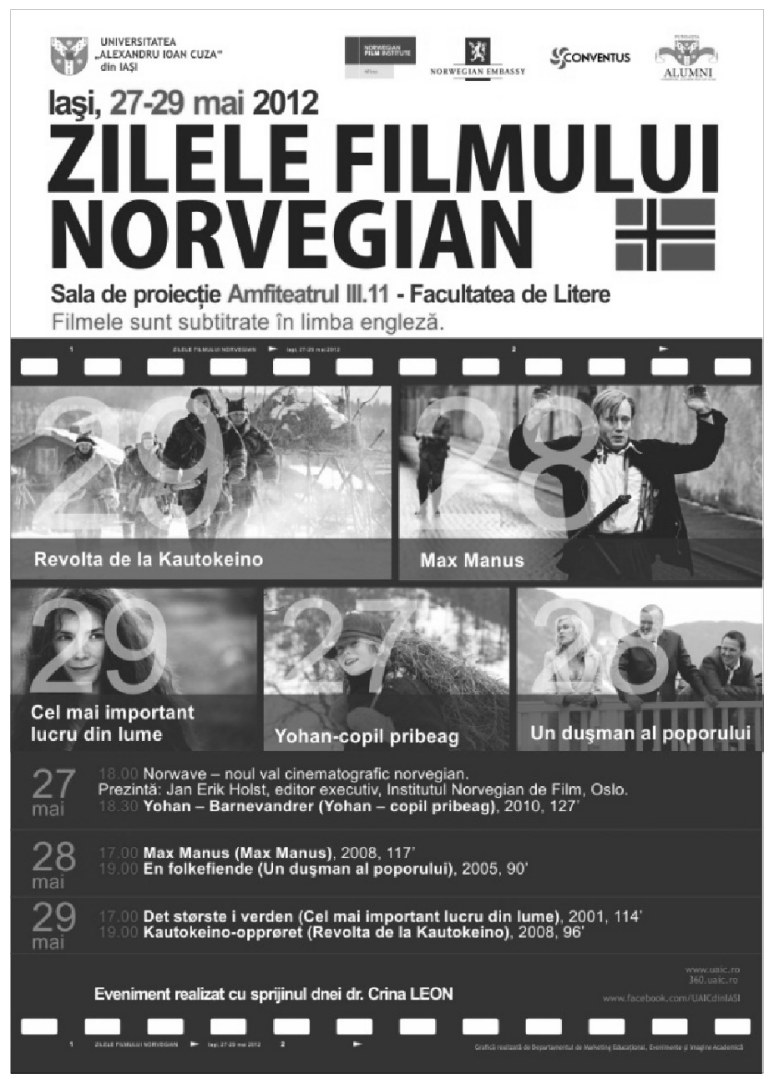

On the occasion of the Norwegian Film Days, Mr. Holst was so kind as to give an interview to several students attending Norwegian courses in Iaşi.

What was it that drove you to the film world so much that you decided to work in this field?

I made film reviews in my childhood and in the school years. I had a book of characters and studied film giving points and stars to films, like a young critic in a way. I have always been fascinated by film, but, as Americans say, there are movies and there are films, and I was more attracted to the movies than to the films, so I had to force myself over to the film and film art. A key moment was when I saw, together with a friend - I was probably 14, maybe younger - "South Pacific", on the big screen, $70 \mathrm{~mm}$, big sound system. We were fascinated. I think we saw it 7 times. And that is a good film school, because if you see a film several times you learn how the language of the film is constructed and how it developed. One time I went to the local cinema and saw a Norwegian film. It was called "Cold Tracks" 1 and it was about the resistance movement during the war, with skiing in the mountains. The contrast between "South Pacific" (big screen, sound, American stars), and this very pure, Norwegian film, made me think I could never be into Norwegian film. After the gymnasium I started the so-called economic education, with evening classes. One day I skipped the evening school and

${ }^{1}$ Kalde spor, 1962, director Arne Skouen 106 
went to the local cinema, and there was a film club there. I saw some films, and again, I had this feeling. I saw a Japanese film by Kurosawa I think, and I did not understand anything, but the others said that that was art, so I accepted it as art. I was elected into the board of the film club and later in the National Society for Film Clubs. Then I started to study at the law school, but dropped it after one year, and worked to promote and distribute films for the film societies. I worked for a couple of years and then I found out that at the University of Stockholm they had a study group in film science and film history, and I attended it. That was very early, in '72, and the study field was very new. We were 5 people from Norway and we were a kind of pioneers. It took many years before film science was established in Norway, first in Trondheim in '75, and much later in Oslo, within the Institute for Media Studies. Also at the National Film School in Lillehammer one can find Film Science. In other places in Norway film itself was not considered as purely scientific or art, so it was combined with media education.

I studied in Stockholm for two years, then came back and started as a cinema manager at the local cinema. I worked for two years as cinema manager and gained a lot of experience during that time. Then I went back to the Film Institute and worked with the film societies again for two years, and afterwards I went back to Stockholm, to the Dramatic Institute, and took education in production management and documentary films, before I started as a producer. I worked as a producer for three years, but I did not like it. As production manager (as a producer) one has to serve other people, and I think promotion, education, and film science were closer to my heart. But I was given an honorary mention as the best production manager in Norway. After receiving this I felt that I had to leave this field. Afterwards, my wife and I made a journey around the world, which was an important experience. We went for half a year to Japan, China, Himalaya, America. On return I took over as manager of the Cinematheque (the art cinema) in Oslo, and then I was appointed head of the Education department and later director at the Film Institute. Since ' 88 I have been at the Film Institute as director in different fields, like production, international relations, archive etc. Now I have a kind of free position as "ambassador". There was a film director in the '60s who told me that if one should be something in Norwegian film, one should have a Bachelor in juridical education, not necessarily full studies, and some basic economic 
studies, let's say two years of juridical studies, two years of economy, then art and science. Then one can be something in film. One does not have to learn film, he said. It is a kind of jack-of-all-trades system, and I remember this: law, economy, philosophy, art but not film, which comes on its own! I do not know if I agree to this today.

\section{Since you have probably seen thousands of films throughout the years, what does a good film mean in your opinion? Can we use this word at all to describe a film?}

Yes, absolutely. I think the best expression comes from a film director and associate professor in Norway, Erik Løchen, who said that if you should make a film, it has to be an important story you tell. I mean, it can be a novel, it can be a social case study, it can be a historical event, but it must be an important case. It must also be important for you. And then, it must be important to tell it on film, so you make a kind of cinematography, you work on the image and the sound and the set design. This is very important for telling the story in pictures. A lot of things can be told on paper. When he was artistic director at the film studios in Oslo, he rejected a lot of people, saying their work was not film, but a newspaper article, or a poem. And, of course, he also said that one shouldn't go to the library and find a book, but instead find the story by themselves. That is a very exclusive way of doing it, but it makes some points I would say. We have experienced this in Norway, and I think more than sixty percent of our films are based on literature. We have a very strong literature from which we bring out the film. Typically it is Henrik Ibsen, Bjørnstjerne Bjørnson, Knut Hamsun etc., and that is good, but it is also dangerous that the film becomes what the Frenchmen call illustratif, meaning only making pictures out of a story and not having a cinematographic approach. There are many ways of doing cinematography, and I would say that if you can express something that is not possible in any other art form, then it is a good film. Because it must have a living approach to it, and it must be, of course, magical, it must be larger than life. It must be something that is driven by suspense or entertainment. American film theories say that there are three genres in film: comedy, melodrama, and action. One has to combine these 
three. Even in documentaries one has to combine them, otherwise it does not work.

In this respect, what are the most important aspects of Norwegian cultural and social nature conveyed by these films?

I would say that nature and landscape as storytelling tools. This is an absolute influence of literature, it stems from Hamsun. Landscape is as a metaphor and in a landscape a lot of things can be developed, especially after the Bergman period. The Bergman films, up to '72-'74, are a sort of chamber play, everything happens inside, people sit and talk, and relations, inner souls and inner development are the key elements. But in Norway we go out. If it is a birth or a death, love scenes, dramatic scenes, everything has to be outside. They even made a kind of film grammar from this. In many Norwegian films if you see a couple going outside, and they want to make love, then the camera goes up along the tree and out to a branch, and then everybody knows what will happen. And it is an interesting scene because it has a kind of discrete protestant approach to it, but it is also a film grammar thing, because it is very economical. Instead of instructing a couple to play a love scene, which takes days to make real, it is easier to film a tree.

Are Norwegian teenagers interested in seeing films at the cinema? How do you think they could be better attracted to a "meeting" with the films?

Yes, they are interested in seeing films, and I think that since 2001 there has been a big change, namely Norwegian teenagers started to see Norwegian films because these films started to be about them. The first film that was really important was "Buddy" 2 . The Norwegian films became preoccupied then with the key target group that went to the cinema; 18 to 25 is the most interesting group. Also very good was the fact that it was not the adult who played in the film for the young people anymore, it was the young people playing for the young people, actors like Aksel Hennie, or the cast of "Max Manus"3. It was a very typical generation thing.

\footnotetext{
2 Buddy, 2003, director Morten Tyldum

${ }^{3}$ Max Manus, 2008, director Joachim Rønning, Espen Sandberg
} 


\section{Is there such a thing as a taboo topic for Norwegian films?}

Yes, I think so. We have not yet made a pornographic film, it might be a hidden taboo. Now we have the situation with Anders Breivik, the terrorist who killed many people, and when somebody wants to make a film out of it, that will be a taboo. If it had been like World War II, it would have been full of stories of heroes. If somebody had chased and killed that terrorist, then that could be made into a film, but the story has no heroes, and psychiatrists cannot agree on whether he is insane or not. You know, there is a story from a mental hospital that is very typical of this situation: in the corridor a man is walking with his toothbrush in a leash. A psychiatrist comes and says "Hello, are you going to a walk with your dog?", and the patient answers "Can't you see this is a toothbrush?". The psychiatrist walks along and the man says to his toothbrush - dog: "Now we fooled them". And this is the situation with Breivik, you cannot say what he is, because all his planning is logical, but the deeds are illogical. So that is a taboo.

We made some films a few years ago, horror films, such as "Dead snow"4 - Nazi zombies, and I think for many people that is a taboo. Also, the same group made a film about the Sami people who were very crazy and evil, it was made after the American film "Kill Bill", and it was called "Kill Buljo"5 (Buljo is a Sami name). I would say that making a film about the Sami people as drinking people, not heroes, is a taboo. We have a kind of high value moral standard and if you scratch that, then that is a taboo.

\section{Generally, how are Norwegian films perceived in Europe and all over the world?}

I think we have had a very good export to Germany for many years. Since, let's say, 1990 there has been big interest in Germany for children's and youth films and social comedies, and especially north Germany has a kind of longing for the Nordic way of life and culture. I remember that around 1990 we had something called Nordic Screening: it was a TV company of the five Nordic countries, and Norddeutscher Rundfunk in Hamburg wanted to be a part of it, so that they felt closer to the Nordic

\footnotetext{
4 Død snø, 2009, director Tommy Wirkola

${ }^{5}$ Kill Buljo - The Movie, 2007, director Tommy Wirkola 110
} 
countries than to Munich. That was interesting and I think that Germany has been a very important market for us. We also sell many films in the Berlin and Lübeck festivals. The last years there has been increasing demand in France, mostly for the philosophical and artistic films, such as "Oslo, August 31st"6, "North"7 or "Elling" 8 , and after that the United States of America have asked for a lot of films, not for major, but for small distributions. Scandinavia is a problem, because we do not see each other's films so much.

\section{What Norwegian films would you recommend to the students at the Alexandru Ioan Cuza University?}

It could be something from the ' $30 \mathrm{~s}$, one or two. We had a very famous director in the '30s, who was called Tancred Ibsen, and he was the grandson of Henrik Ibsen and Bjørnstjerne Bjørnson. He made some adventure films. One of them is called "Tramp" 9 and is about travelling people that are typical of Scandinavia. They go by sea and they are called fant or they go by land and they are called tater. So from the '30s it could be either "Fant" or "Gjest Baardsen"10, a story about a Norwegian Robin Hood. And then we could go to the ' 50 s when we had good directors and authors, such as Edith Carlmar. She was the first female director, and made a sort of film noir, a film called "Death is a caress"11. In the "60s there are the films by Erik Løchen, one of which is called "The Hunt" 12 , influenced by Bertolt Brecht. In the '70s there is a lot of social realism, and we have a very important director called Anja Breien. We have a DVD with all her short films. She made "Wives"13, that is a kind of female version of John Casavetes" "Husbands", and it is an improvisation with three women that go out and leave their children and husbands behind. They go out to drink and travel, and they do not come back. There is in the film one sentence that is fantastic: "Happy Christmas, it's all in the freezer", and they leave.

\footnotetext{
6 Oslo, 31. august, 2011, director Joachim Trier

7 Nord, 2009, director Rune Denstad Langlo

8 Elling, 2000, director Petter Næss

${ }^{9}$ Fant, 1937, director Tancred Ibsen

10 Gjest Baardsen, 1939, director Tancred Ibsen

11 Døden er et kjærtegn, 1949, director Edith Carlmar

12 Jakten, 1959, director Erik Løchen

13 Hustruer, 1975, director Anja Breien
} 
That was revolutionary in 1975. And in the '80s we have "Orion's belt"14 that is a detective and political story. That changed a lot of the Norwegian history, because in ' 85 we had a conservative government for the first time in many years, and they left the social-democratic approach. The difference in cultural aspects between the social-democrats and the conservatives is that the conservatives want more private investment while the socialdemocrats want more public investment. Also from the '80s was "The Pathfinder"15, which was a very interesting story. A young Sami actor came to the producer with this story, he believed in it, and he developed the film in England with an international crew. The producer was very skilled in distributing the film, so it was distributed in America and it was nominated for Oscar and had worldwide distribution. And maybe also the adventure film "Pinchcliffe Grand Prix"16. It is an animation film made in '75 and very popular. It has been running in the cinema ever since, so it reached a target of 5 million people. It is a very funny film and very Norwegian in a way, with different types of characters, such as the skeptical one and the overenthusiastic one. It was made by an Italian born filmmaker called Ivo Caprino. And then, in recent years there are many films to choose from, but I would say maybe a film from 1989, called "A handfull of time"17. That is a story about an old man who travels across the mountains from Oslo to Bergen. He has a conversation with his wife, but the wife died when they were young. He meets an English couple, who have a kind of philosophy that time is not something that is developed chronologically. Time is what happens at the same time in different years, and he tries to prove it by saying that the mountains are the same as 100 years ago, so maybe they had this conversation 100 years ago. This kind of philosophical approach is very seldom in Norwegian films. It is very seldom in Norwegian literature as well, because very much of Norwegian literature is story telling. So this film is remarkable, with beautiful landscape as well.

\footnotetext{
14 Orions belte, 1985, director Ola Solum

15 Veiviseren, 1987, director Nils Gaup

16 Flåklypa Grand Prix, 1975, director Ivo Caprino

${ }^{17}$ En håndfull tid, 1989, director Martin Asphaug

112
} 
From your standpoint, how were Norwegian films perceived in Romania and how do you believe they should be better promoted in the future?

I think that the Transilvania International Film Festival (TIFF) is very important, and I think some films have been sold after TIFF. But normally the best way to promote a film is in the market in Cannes and Berlin, and the best is if TIFF organizers go to a distributor and ask them to buy a film because they want it for the festival. And then the film has a distributor at a local festival, which is the best case. Then, they can use the festival as a national promotion, and that is the best, because a film is a kind of fresh food, it has to be new. So it is not always the best thing to send 5 films to TIFF and hope that they are all sold to Romania. What does not work in a sale perspective, is when we have films at an EU festival or a Cultural Center. Then they are part of a cultural promotion. We have experience that a national festival can promote a film very well with a local distributor. And that also goes for B-festivals. What is very important is that people in Romania get a kind of overall knowledge about Norwegian films, and then festivals, small festivals like the Norwegian Film Days in Iaşi, in Cluj-Napoca and even Bucharest are very important, because when a Norwegian film comes to the cinema, people will think that they have previously seen some Norwegian film and it was very good. It is very typical that you remember the nationality if the film is bad, but if the film is good then why remember the nationality? Yet, what is important is that it is a different kind of film, different from other cultures. I personally like very much the combination of film and art and music and theater. We do not have a kind of Norwegian cultural export system, like the Swedes and the Danes, but we have different small institutes, and we cooperate together: NORLA (that promotes Norwegian literature abroad), OCA (that promotes visual art abroad), Music Export Norway etc.

\section{What can you tell us about the film Oslo, August 31st? ${ }^{18}$ Does it say anything about Norwegian society today?}

I think this film could have been made in any European country. It is made after a French novel, written by Pierre Drieu La Rochelle, which is part of the success it has had. Those who made it (Joachim Trier - director and Eskil Vogt - writer) are very international, from the London (Trier) and 
Paris (Vogt) film schools. I would not say it is typical Norwegian in a way, but it is a typical big city film, and it shows the alienation of the young people who cannot find the meaning of life and peace in big cities, because there is a great demand, both personal and social, on how to develop. A key element is that art and literature play such an important role for them. They try to be characters in a novel instead of living their lives, and they talk about themselves as characters in novels. That was also the theme in the first film this team made together, "Reprise"19. So it is a very artificial story in a way, and fascinating, but it is not typical Norwegian. It could be made here in Romania, Italy, and France, but maybe not in Germany, because it is an intellectual approach and an intellectual problem, and I would say in Germany it would have been an environmental or industrial problem.

Every country or cultural space should be able to find its own way in cinematography. As an exterior observer who has visited Romania several times, what do you consider to be the strong points of the local cinematographic industry? What themes do you consider to be worth exploiting more?

I would like to see more films about the communist period and good people and bad people during the Ceauşescu regime, but what I cannot understand is how Romania, with so much art and culture and science and universities, could create such a regime. I cannot see the hierarchic mentality here as it exists in other countries. So I do not understand, and I would like to see more works about that. But from what I have seen in Romanian films, moral and intellectual questions are very well treated. In every Romanian film I have seen, they talk about essential problems, they talk about essential stories, there is social realism with a philosophical frame, and that is very different from Scandinavia. In Scandinavia we often talk about nothing, there is no conflict of discourse.

\section{How do you feel that the Norwegian films were received in Iaşi?}

I feel that they were well received because they are different, different from the Romanian film and the American film, which is the

19 Reprise, 2006, director Joachim Trier 114 
mainstream, and indirectly tell things about our country: the landscape, as I have already mentioned, but also human relations. I think that what we have in common in all the films is a common struggle for a better life. Maybe in Latin countries it is not a struggle for a better life, but it is a kind of discussion about how the life was or should have been. We are Protestants, and the protestant always struggles for better: better economy, more children, more of everything. Romanians sit and discuss the past and see what they can learn from that, while we do not have this historical and philosophical approach. The lack of philosophy is a very Scandinavian thing. I think it comes from religion, because we cannot go and ask for forgiveness in the church. In Scandinavia we often have burdens on our back. 